\title{
Analysis of Factors Affecting the Workload of Health Workers in the Namrole Public Health Center and Wamsisi Public Health Center in South Buru Regency
}

\author{
Harun Pattah ${ }^{1}$, Muhammad Alwy Arifin², Indar², Darmawansyah², \\ Anwar Daud $^{3}$, Aminuddin Syam ${ }^{4}$, Anwar Mallongi ${ }^{3}$ \\ ${ }^{I}$ Magister Program Department of Health Administration and Policy, Public Health Hasanuddin University, \\ ${ }^{2}$ Professor of Department of Health Administration and Policy, Public Health Hasanuddin University, ${ }^{3}$ Professor \\ of Department of Environmental Health, Public Health Hasanuddin University, ${ }^{4}$ Senior lecturer of Departemenof \\ Nutrition, Faculty of Public Health, Hasanuddin University
}

\begin{abstract}
The workload on health workers in Public health centers can be seen from aspects such as tasks that are carried out based on their main functions. The purpose of this study was to analyze the factors that influence the workload of health workers in the Namrole Public health center and the WamsisiPublic health center in South Buru Regency. This type of research is a quantitative cross-sectional study design. The population in this study were all health workers with the status of civil servants who worked in the NamrolePublic health center as many as 73 officers and WamsisiPublic health center as many as 27 officers. The sampling technique in this study was proportional random sampling to obtain a sample of the NamrolePublic health center as many as 58 officers and WamsisiPublic health center as many as 22 officers. The results showed that there was no influence of the level of education on the workload of health workers in the Namrolepublic health center and the Wamsisipublic health center in South Buru regency $(p=0.622>0.05)$. Working time significantly affected the workload $(\mathrm{p}=0.000<0.05)$ and years of service are protective factors for the workload of employees at the Namrolepublic health center and the Wamsisipublic health center in South Buru regency $(\mathrm{p}=0.053>0.05)$. To the Regional Government of South Buru Regency to emphasize more regulations related to working hours, especially for employees at public health care centers, so that they are able and comfortable to carry out their duties and functions effectively and efficiently with optimal work time and not excessive.
\end{abstract}

Keywords: Workload, work time,Wamsisi Public Health Center, Namrole Public Health Center.

\section{Introduction}

Workloads on healthcare personnel in public health centres can be seen from aspects such as tasks that are executed based on their main functions. Tasks that carried out include basic tasks, additional tasks/ double, the number of patients who should be served,

\footnotetext{
Corresponding Author:

Harun Pattah

Magister Program Department of Health Administration and Policy, Public Health Hasanuddin University e-mail: harunpattah3@gmail.com
}

the working capacity in accordance with the education of health workers, the working time used to work on the task in accordance with the working hours of the day, as well as the completeness of facilities that can help the health workforce in solving their work well. ${ }^{1}$

The Public health Center is a healthcare facility that organizes public health efforts and first-rate individual health efforts, with a greater emphasis on promotive and preventive efforts, to achieve the highest degree of public health in its working area ${ }^{2}$.

Based on the results of the research Nafizta, showing the calculation and analysis of the workload of 
the nurses using the work sampling method resulted that the workload on 6 working days of nursing workers in the public health center Poncol differ. Nursing personnel workloads are the highest on Mondays and Thursdays during long working hours, while for short working hours the highest workload of caregivers is on Saturday. ${ }^{3}$

Namrole Public Health Center and Wamsisi Public Health Center are two public health centres located in the South Buru regency. Namrole Public Health Center and Wamsisi Public Health Center is a health service with inpatient unit based on the visit data that is obtained shows that patients who come to the public health center are many and tend to increase, since the NHI era, number of visits in Namrole Public Health Center in 2018 as many as 13,858 patients and in 2019 as of October 17,157 patients ${ }^{4}$ Meanwhile, in the Public health center of Wamsisi in 2018 as many as 7,556 patients and in the year 2019 as of October 4,934 patients ${ }^{5}$. The aim of the study was to analyse the factors affecting the workload of healthcare personnel at the Namrole Public Health Center and the Public Health center of South Buru Regency.

\section{Materials and Method}

This research uses quantitative research method of cross sectional study design. The population in this research is all health officers who are the status of civil servants who work in the Namrole Public Health Center, which is 73 officers and the Public health center of Wamsisi is as many as 27 officers. The sampling technique in this study is proportional random sampling so that the information obtained by the Namrole Public Health Center is as many as 58 officers and the Public health center of Wamsisi is as many as 22 officers. Data collection is obtained through a live interview using a questionnaire.

\section{Results}

Based on table 1 shows respondents who are 26-35 years more than 55 people $(68.8 \%)$, while the respondents are the least in the age group of 18-25 who are 9 people $(11.2 \%)$. According to the gender the number of female respondents was more than 69 people $(86.2 \%)$, while male respondents were only 11 people $(13.8 \%)$ While based on the working area of the number of respondents working in the Namrole Public Health Center as many as 58 people $(72.5 \%)$, while the respondents who worked in wamsisi public health centers as many as 22 people $(27.5 \%)$.

Table 1. Distribution of Respondents based on Characteristics of Respondents in Namrole public health centers and Wamsisi public health centers in $\mathbf{2 0 2 0}$

\begin{tabular}{|c|c|c|}
\hline Characteristics of Respondents & Amount (n) & Percent (\%) \\
\hline a. $\begin{array}{l}\text { Age }(\mathbf{y r}) \\
18-25 \\
26-35 \\
36-45\end{array}$ & $\begin{array}{c}9 \\
55 \\
16\end{array}$ & $\begin{array}{l}11.2 \\
68.8 \\
20.0\end{array}$ \\
\hline Total & 80 & 100 \\
\hline $\begin{array}{ll}\text { b. } & \text { Gender } \\
\text { Male } \\
\text { Girl }\end{array}$ & $\begin{array}{l}11 \\
69\end{array}$ & $\begin{array}{l}13.8 \\
86.2\end{array}$ \\
\hline Total & 80 & 100 \\
\hline $\begin{array}{l}\text { c. Working area } \\
\text { Namrole public health center } \\
\text { Wamsisipublic health center }\end{array}$ & $\begin{array}{l}58 \\
22\end{array}$ & $\begin{array}{l}72.5 \\
27.5\end{array}$ \\
\hline Total & 80 & 100 \\
\hline
\end{tabular}

Source: 2020 Primary Data 
Table 2. Effects of education, work time and work period on workloads Namrolepublic health center and Wamsisipublic health center 2020

\begin{tabular}{|c|c|c|c|c|c|c|c|}
\hline \multirow{3}{*}{ Research variable } & \multicolumn{4}{|c|}{ Workload } & \multirow{2}{*}{\multicolumn{2}{|c|}{ Total }} & \multirow{3}{*}{ P. } \\
\hline & \multicolumn{2}{|c|}{ Light } & \multicolumn{2}{|c|}{ Weight } & & & \\
\hline & $\mathbf{n}$ & $\%$ & $\mathbf{N}$ & $\%$ & $\mathbf{N}$ & $\%$ & \\
\hline Education & & & & & & & \multirow{4}{*}{0.622} \\
\hline High & 54 & 72 & 21 & 29 & 75 & 100.0 & \\
\hline Low & 3 & 60 & 2 & 40 & 5 & 100.0 & \\
\hline Total & 57 & 71.3 & 23 & 26 & 80 & 100.0 & \\
\hline \multicolumn{7}{|l|}{ Working time } & \multirow{4}{*}{0,00} \\
\hline Normal & 44 & 93.6 & 3 & 6,4 & 47 & 100.0 & \\
\hline Abnormal & 13 & 39.4 & 20 & 60.6 & 33 & 100.0 & \\
\hline Total & 57 & 71.3 & 23 & 28.7 & 80 & 100.0 & \\
\hline \multicolumn{7}{|l|}{ Years of service } & \multirow{4}{*}{0,00} \\
\hline Enough & 49 & 89.1 & 6 & 10.9 & 55 & 100.0 & \\
\hline Less & 8 & 32.0 & 17 & 68.0 & 25 & 100.0 & \\
\hline Total & 57 & 71.3 & 23 & 28.7 & 80 & 100.0 & \\
\hline
\end{tabular}

Table 2 shows that from 50 respondents that the variable is located from 80 respondents there are 75 people who are highly educated, who are 54 people $(72 \%)$ Of those who felt a mild workload and 21 people $(28 \%)$ The rest feels its burden is quite heavy. Meanwhile, out of 5 low-educated respondents were 3 people $(60 \%)$ That feels it has a lightweight workload and 2 people $(40 \%)$ have heavy workloads. Statistical test result $\mathrm{X}^{2}$ Fisher's Exact Test obtained the value $\mathrm{P}=0,622$ or value $\mathrm{p}>0.05$, thus Ho accepted and Ha rejected. So it can be concluded that there is no meaningful relationship between the level of education and the workload of health workers in the Namrole public Health Center and wamsisi Public Health center in 2020.

Based on the variable working time table 2 shows that from 80 respondents there were 47 people who had normal working time, of which 44 people $(93.6 \%)$ Of those who felt the burden of light and 3 people (6.4\%) The rest feels its burden is quite heavy. While from 33 respondents who have abnormal working time, there are 13 people (39.4\%) That feels it has a lightweight workload and 20 people $(60.6 \%)$ Others feel that the workload is quite heavy. The test result of the Ikchisquare Statistic is derived from the value $p=0,000$ or $\mathrm{P}$ value $<0.05$, thus Ho is rejected and Ha is accepted. So it can be concluded that there is a meaningful relationship between working time with the workload of health workers in the Namrole public Health Center and the wamsisi public Health Center in 2020.
Based on a working period variable table 2 shows that from 80 respondents there were 55 people who had sufficient employment, of which 49 people $(89.1 \%)$ Of those who felt a mild workload and 6 people $(10.9 \%)$ The rest feels its burden is quite heavy. As for 25 respondents who have a less working period, there are 8 people $(32.0 \%)$ That feels it has a lightweight workload and 17 people $(68.0 \%)$ Others feel that the workload is quite heavy. The test result of the Ikchi-square Statistic is derived from the value $\mathrm{p}=0,000$ or $\mathrm{P}$ value $<0.05$, thus Ho rejected and $\mathrm{Ha}$ accepted, so that there is a meaningful relationship between the working time with the workload of health care in the Namrole public Health Center and the wamsisi public health center in 2020.

\section{Discussion}

Effect of education on workload: From the analysis results with the $\mathrm{X}^{2}$ statistical test Likelihood Ratio obtained the value $\mathrm{P}=0.622(\mathrm{P}>0.05)$, thus there is no link between the level of education with the workload. It is in accordance with the research of Umamah which proves that there is no link between the level of education and the workload. The research is also in line with the findings of VenyYuliani (2017) which proves there is no link between the level of education and the workload with the value $\mathrm{P}=0.17>0.05$.

Meanwhile, Maryam (2017) states that performance is heavily influenced by the internal factors of workload 
i.e. education level. This is because the higher the mastery of one's intellectual degree, the more it is open ability to increase the productivity of its work. In addition to the higher level of education of a person, the likelihood of analyzers in addressing problems is also higher.

Effect of working time on workloads: Everyone has been stressed and will experience it, but the levels vary and within the same period ${ }^{6}$. Nurazizah states that stress is a thorough response from both physical and mental bodies to any demands or disturbing changes, threatening security and individual self-esteem ${ }^{7}$.

Working in a public health center in every opportunity will meet patients with varying characteristics that impact different conditions and workloads. For that, Nurses should act as all-round personnel, have initiatives, behave creatively and have a broad insight with the motivation of hard work, intelligent, sincere and quality work. The types of patients who are hospitalized or treated in an inpatient room can be viewed as a claim to health care if not managed properly, it will result in stressful work ${ }^{7}$.

The results of this research in line with the research of SrieWulandari, et al. (2017) said that the workload in the Emergency Instaltance space is heavy because it has to do the treatment of patients who come quickly and precisely ${ }^{8}$. According to research Nurazizah is known to occur decrease in overall brain function. With a tool that can display the picture of the brain using advanced technology, it is found that more severe damage occurs in areas responsible for attention, complicated planning, complex mental processes and on the area of decision making.

The excess sleep time also poses a problem, theoretically if the body is too much sleep, then blood circulation becomes slow. The impact will be about the whole body, because metabolism will also slow down. If it happens for a long time then the condition will cause a variety of problems. According to him, shift work affects health in the first 5 (five) years, called the adaptation phase ${ }^{9}$.

Effect of working period on workload: Through analysis with the Chi-Square test obtained the value $\mathrm{P}$ $=0,000(\mathrm{P}<0.05)$, thus there is a relationship between the working period and the workload. The results of this study are in line with the findings of Zulkifli, DKK (2018) stating that the longer working life is closely related to the experience and understanding of the better job description. This experience and understanding will assist in addressing the problem (stresor) that exist in the prevention of stress due to excessive workload ${ }^{10}$.

Meanwhile, the results of this research are contrary to the research results of VennyYulianti which says that there is no relationship between the working period and the workload with the value $\mathrm{P}=0.91(\mathrm{p}>0.05)^{11}$. This is due to the longer the working period, the greater the burden and responsibilities of the employees. The difference in workers whose work period is less than 5 years still needs self-adjusting with the working environment and any work risk that can occur. Because of the negative impact for a company if it gives a mental workload too high or too low for employees, it provides special attention to the right mental workload for its employees. Additionally, respondents who experienced the dominant heavy workload have been working long enough ( $>5$ years). It can be assumed in addition to the effect of demands on speed of work, thoroughness and prudence there are also other factors that cause heavy workload that is also boredom due to the destruction of the work.

In overcoming the boredom of work because the specialization of work is required the right solution. Changing tasks can increase the stimulation of mental workers or passions, as well as the involvement of their duties, so that it can improve performance within the company ${ }^{11-15}$. Many companies do a variety of work boredom prevention measures to make workers not feel bored with the activities that must be done daily, by conducting work rotation, involving workers in decision making, conducting the meeting of all employees, giving the opportunity to do leave, and many other things. All these activities aim to prevent or reduce the boredom of work on employees. ${ }^{17}$

\section{Conclusion}

The research concluded that there was no level of education on the workload of healthcare personnel at the Namrole Public Health Center and the WamsisiPublic Health center of the South Buru regency $(p=0,622>$ $0.05)$, the working time significantly affects the workload $(\mathrm{P}=0.000<0.05)$ and the working period is a protective factor against personnel workloads in the Namrole Public Health Care Center and the wamsisiPublic Health center of the South Buru regency $(p=0,053>0.05)$. To the local government of South Buru Regency to be more emphasized regulation related to working hours 
especially for employees at the Public health Care center, so that they can afford and comfortably fulfill their duties and functions effectively and efficiently with optimal uptime and not excessive

Ethical Clearance: Taken from University ethical committee.

Source of Funding: Self

Conflict of Interest: Nill

\section{References}

1. Barahama, K.F., M. Katuuk, and W.M. Oroh, HUBUNGAN BEBAN KERJA DENGAN KEPUASAN KERJA PERAWAT DI RUANGAN PERAWATAN DEWASA RSU GMIM PANCARAN KASIH MANADO. JURNAL KEPERAWATAN, 2019. 7(1).

2. Permenkes No 75 Tahun 2014, Tentang Puskesmas. 2014, Menteri Kesehatan: Jakarta.

3. Rizcarachmakurnia, N., P.A. Wigati, and A. Sriatmi, Analisis beban kerja dan kebutuhan tenaga perawat di Puskesmas Poncol Kota Semarang. Jurnal Kesehatan Masyarakat (e-Journal), 2017. 5(3): p. 26-32.

4. Profil Puskesmas Namrole, Profil Puskesmas Namrole Tahun 2018. 2018, Puskesmas Namrole: Kabupaten Buru Selatan

5. Profil Puskesmas Wamsisi, Profil Puskesmas Wamsisi Tahun 2018. 2018: Kabupaten Buru Selatan.

6. Chandra, R. and D. Adriansyah, Pengaruh beban kerja dan stres kerja terhadap kinerja karyawan pada PT. Mega Auto Central Finance Cabang di Langsa. Jurnal manajemen dan keuangan, 2017. 6(1): p. 670-678.

7. Nurazizah, Faktor-Faktor yang Berhubungan dengan Stres Kerja Pada Perawat di Ruang Rawat Inap Kelas III RS X Jakarta Tahun 2017, in Program Studi Kesehatan Masyarakat. 2017, UIN Syarif Hidayatullah Jakarta: Fakultas Kedokteran dan Ilmu Kesehatan, 2017: Jakarta.

8. Srie, W., S. Samsir, and J.M.M. Rio, Analisis Beban Kerja Mental, Fisik Serta Stres Kerja Pada Perawat Secara Ergonomi Di RSUD Dr. Achmad Mochtar Bukittinggi. Jurnal Online Mahasiswa Fakultas Ekonomi Universitas Riau, 2017. 4(1): p. 954-966.
9. Lestya, D.N.W., F. Rachman, and W. Wiediartini. Analisis Faktor Eksternal dan Internal Yang Mempengaruhi Beban Kerja Fisik Pada Pekerjaan Finishing Di Perusahaan Fabrikasi Baja. in Seminar K3. 2017.

10. Zulkifli, Z., S.T. Rahayu, and S.A. Akbar, Hubungan Usia, Masa Kerja dan Beban Kerja Dengan Stres Kerja Pada Karyawan Service Well Company PT. ELNUSA TBK Wilayah Muara Badak. KESMAS UWIGAMA: Jurnal Kesehatan Masyarakat, 2019. 5(1): p. 46-61.

11. Birawida, A. B., M. Selomo, and U. W. Ismita. "Environmental health hazards against bacterial contamination of cutlery on the small island of Makassar.” E \& ES 235.1 (2019): 012023.

12. Kayame, R., Mallongi, A. Relationships between smoking habits and the hypertension occurrence among the adults of communities in paniai regency, Papua Indonesia.Indian Journal of Public Health Research and Development 2018; Volume 9, Issue 1, Pages 332-336

13. Endah Yani, R.W., Mallongi, A., Andarini, S., Prijatmoko, D., Dewanti, I.R. The effect of zinc saliva on the toddlers' nutritional status. Journal of International Dental and Medical Research, 2016, Volume 9, Issue 1, Pages 29-32

14. Birawida, A.B., Selomo, M., Mallongi, A. Potential hazards from hygiene, sanitation and bacterium of refill drinking water at Barrang Lompo island (water and food safety perspective) IOP Conference Series: Earth and Environmental Science 2018; Volume 157, Issue 1, Article number 012034

15. Russeng, S.S., Saleh, L.M., Virani, D., Latief, A.W.L., Mallongi, A. The investigation of the lactic acid change among employee of national electrical power plan. Indian Journal of Public Health Research and Development 2018; Volume 9, Issue 1, Pages 361-365

16. Rosmala Nur, Siti Ika Fitrasyah, Anwar Mallongi, Women's Reactions and Health Disorders Caused by Abuse During the Pregnancy-Postpartum Period. Medico-legal Update, January-March 2020, Vol.20, No. 1

17. Binti Nurasyad, V.Y., Faktor yang Berhubungan dengan Beban Psikososial pada Karyawan PT. Eastern Pearl Flour Mills. 2017, Universitas Islam Negeri Alauddin Makassar. 